\title{
Fatal intoxication with U-47700 in combination with other NPS ( $N$-ethylhexedrone, adinazolam, 4-CIC, 4-CMC) confirmed by identification and quantification in autopsy specimens and evidences
}

\author{
Karolina Nowak $^{1,2}$ (D) Paweł Szpot ${ }^{1,2}$ - Marcin Zawadzki ${ }^{1,2}(\mathbb{D}$
}

Received: 12 September 2020 / Accepted: 22 December 2020 / Published online: 19 January 2021

(c) The Author(s) 2021

\begin{abstract}
Purpose We present a case of fatal intoxication with U-47700 in combination with other NPS ( $N$-ethylhexedrone, adinazolam, 4-chloro- $N$-isopropylcathinone (4-CIC), 4-chloromethcathinone (4-CMC) and sertraline) confirmed by identification and quantification in biological materials and evidences found at the scene in 2017 in Poland.

Methods Blood and urine samples were extracted with ethyl acetate from alkaline medium ( $\mathrm{pH}$ 9); powders/crystals were diluted with methanol. The analysis was carried out using ultra-high-performance liquid chromatography-tandem mass spectrometry. Validation criteria were evaluated for blood and urine at the concentrations of 10 and $100 \mathrm{ng} / \mathrm{mL}$.

Results The validation parameters of the method were within acceptable ranges. In the presented case, the determined concentrations of drugs were as follows, in blood: U-47700, $1470 \mathrm{ng} / \mathrm{mL} ; N$-ethylhexedrone, $58 \mathrm{ng} / \mathrm{mL}$; adinazolam, $18 \mathrm{ng} /$ $\mathrm{mL}$; 4-CIC, $8.0 \mathrm{ng} / \mathrm{mL}$; 4-CMC, $1.7 \mathrm{ng} / \mathrm{mL}$; in urine: U-47700, $3940 \mathrm{ng} / \mathrm{mL} ; N$-ethylhexedrone, $147 \mathrm{ng} / \mathrm{mL}$; adinazolam, $82 \mathrm{ng} / \mathrm{mL}$; 4-CIC, $130 \mathrm{ng} / \mathrm{mL}$; 4-CMC, $417 \mathrm{ng} / \mathrm{mL}$. Sertraline (blood, $89 \mathrm{ng} / \mathrm{mL}$; urine, $32 \mathrm{ng} / \mathrm{mL}$ ) was also determined in both materials. The same substances were also found in 5 powders/crystals: U-47700 (12\% by weight), $N$-ethylhexedrone (54\%), adinazolam (14\%), 4-CIC (23\%), 4-CMC (26\%). After 775 days of storage, biological samples at $+4{ }^{\circ} \mathrm{C}$, the most stable substance was sertraline and the less, synthetic cathinones, especially 4-CIC and 4-CMC.

Conclusions The described case of fatal intoxication with NPS presented postmortem concentrations of U-47700, 4-CMC, $\mathrm{N}$-ethylhexedrone, adinazolam and 4-CIC for the first time in the literature. The paper also showed stability study of these substances stored at $+4{ }^{\circ} \mathrm{C}$ for 775 days.
\end{abstract}

Keywords U-47700 · 4-CIC · Adinazolam $\cdot 4$-CMC $\cdot N$-Ethylhexedrone $\cdot$ NPS

\section{Introduction}

Supplementary Information The online version contains supplementary material available at https://doi.org/10.1007/s1141 9-020-00568-1.

Karolina Nowak

karolina_nowak1@wp.pl

1 Department of Forensic Medicine, Wroclaw Medical University, 4 J. Mikulicza-Radeckiego Street, 50-345 Wrocław, Poland

2 Institute of Toxicology Research, 45 Kasztanowa Street, 55-093 Borowa, Poland
According to the EMCDDA [1], in 2017, opioids (often heroin) were involved in between 8 and 9 of every 10 druginduced deaths reported in European countries. Among new synthetic opioids (NSOs), we classify prescription opioid analgesics (e.g., oxycodone), legal and illegal fentanyl analogs (e.g., acetyl fentanyl), and opioid drug candidates (e.g., benzamide derivates). Substances from this group pose a threat to public health in many countries, especially in Europe and the USA [2]. U-47700 has been already detected in, e.g., Belgium (2016) [3], where in 2017 it was involved in 5 deaths [4], as well as in Finland (10 deaths in 2016 and 2017) [5], Italy (2017) [6], Poland [7], the United Kingdom 
[8], Germany [9], and the USA (e.g., Texas, California, Tennessee, Kansas) [8].

U-47700 (3,4-dichloro- $N$-[(1R, 2R)-2-(dimethylamino) cyclohexyl]- $N$-methylbenzamide), also known as $\mathrm{U} 4$ or fake morphine, is categorized as a fentanyl-related synthetic opioid, a selective $\mu$-opioid receptor agonist. Its potential in animal models is estimated to be approximately 7.5 times greater than morphine [10]. U-47700 is available for illegal sale as a substitute for heroin or oxycodone or sold in combination with other drugs (e.g., fentanyl). Particularly dangerous one seems to be a drug called 'Gray Death', which appeared on the streets in the Southeastern United States in 2019. Actually, 'Gray Death' is a random combination (depending on each mixture) of U-47700 with fentanyl, carfentanil, furanyl fentanyl, heroin, or other illicit opiates [11]. Nikolau et al. [12] also paid attention to scientific papers describing cases of intoxication or deaths related to U-47700 alone, or in combination with alcohol, medicinal, controlled drugs, new psychoactive substances (NPS; especially fentanyl or its analogues). Routes of administration include oral, intravenous, insufflation, and rectal [13]. The substance demonstrates opiate-like adverse effects, e.g., cyanosis, pinpoint pupils, respiratory depression, and depressed consciousness. According to users' reports, U-47700 may induce tolerance and dependence [13].

The substances 4-chloromethcathinone or 4-CMC (1-(4-chlorophenyl)-2-(methylamino)-propan-1one), 4-chloro- $N$-isopropylcathinone or 4-CIC (1-(4-chlorophenyl)-2-(isopropylamino)-propan-1-one), and $N$-ethylhexedrone or $\alpha$-ethylaminohexanophenone (2-(ethylamino)-1-phenylhexan-1-one) belong to the group of synthetic cathinones, popular all over the world. According to the European Drug Report 2018 [14] in 2016, 4-CMC was the second most frequently confiscated cathinone in Europe and the one seized in the largest amounts $(890 \mathrm{~kg})$. The literature contains cases of deaths related to the use of synthetic cathinones, individually or in combination with substances from other groups [7, 15-20].

Adinazolam (1-(8-chloro-6-phenyl-4H-[1,2,4] triazolo[4,3-a][1,4] benzodiazepin-1-yl)- $N, N$-dimethylmethanamine), also known as adinazolamum or deracyn ${ }^{\circledR}$, belongs to the triazole-benzodiazepine group; however, it has never been approved by the FDA or marketed as a licensed drug [21]. It was detected for the first time in Europe in 2015 [22]. Until now, this substance has not been detected in postmortem material.

The reported case concerns a fatal overdose of U-47700 in combination with $\mathrm{N}$-ethylhexedrone, adinazolam, 4-CIC, 4-CMC, and sertraline. Figure 1 shows chemical structures of compounds dealt with in this report. We present, for the first time, concentrations of adinazolam and 4-CIC in autopsy materials. In addition, we present the results of stability studies of the identified substances following storage of the tested biological material for 775 days at $+4{ }^{\circ} \mathrm{C}$. We also present quantifications of evidences found at the scene.

\section{Case history and pathological findings}

The body of a 24-year-old woman was found in her bed in the apartment where she lived with her mother. Five resealable bags with unidentified powders/crystals were found at the scene (Fig. 2). The obtained information indicated that the woman had undergone drug addiction therapy due to her addiction to NPS and had attempted suicide several times in the past. Due to the suspicion that death was caused by intoxication with unknown substances, an autopsy was performed, along with toxicological analyses of biological materials and powders/crystals found at the scene. The autopsy showed no obvious pathological changes in the organs of the deceased.

\section{Materials and methods}

\section{Chemicals}

Water $\quad\left(\right.$ Chromasolv ${ }^{\circledR}$ LC-MS), acetonitrile (Chromasolv ${ }^{\circledR}$ LC-MS), methanol (Chromasolv ${ }^{\circledR}$ LC-MS) ethyl acetate, and formic acid were purchased from SigmaAldrich (Steinheim, Germany); ammonium formate from Sigma-Aldrich (Bangalore, India); ammonium carbonate from Fluka (Buchs, Switzerland); 4-CMC, U-47700, $N$-ethylhexedrone, sertraline, fentanyl- $d_{5}$, quetiapine- $d_{8}$ and diazepam- $d_{5}$ from Cerilliant (Round Rock, TX, USA); adinazolam, 4-methylmethcathinone- $d_{3}$ (4-MMC- $\left.d_{3}\right), 4$-CIC from LGC Standards (Dziekanów Leśny, Poland). The internal standards (ISs) were prepared in methanol.

\section{Biological material}

For the development and validation of the method, drugfree blank blood samples were obtained from a regional blood donation center, and drug-free blank urine samples were obtained from healthy volunteers. Blood and urine samples were collected into glass tubes containing sodium fluoride $(\mathrm{NaF})$ /sodium heparin (5-mL glass BD Vacutainer ${ }^{\circledR}$, $\mathrm{NaF}-4 \mathrm{mg} / \mathrm{mL}$; sodium heparin-28 IU/mL, REF 367,764; Plymouth, U.K.) and sent to the Institute of Toxicology Research, Borowa, Poland, for routine toxicological analysis, where they were stored at $+4{ }^{\circ} \mathrm{C}$.

\section{Working solutions, calibration curve, and quality control samples}

The working solutions of different concentrations were prepared by dilution of the standards solutions with methanol. The stock and standard solutions were stored at $-20^{\circ} \mathrm{C}$. 


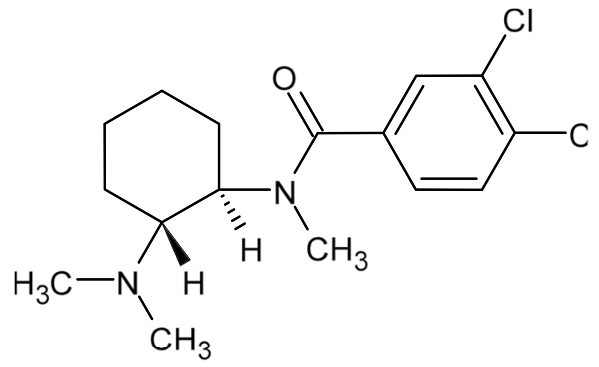

$\mathrm{U}-47700$<smiles>CCCCC(NCC)C(=O)c1ccccc1</smiles>

$N$-Ethylhexedrone

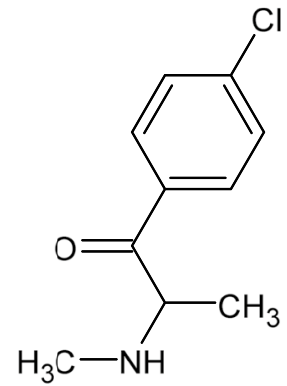

4-Chloromethcathinone

(4-CMC)<smiles>CN(C)Cc1nnc2n1-c1ccc(Cl)cc1C(c1ccccc1)=NC2</smiles>

Adinazolam<smiles>CC(C)NC(C)C(=O)c1ccc(Cl)cc1</smiles>

4-Chloro- $N$ isopropylcathinone (4-CIC)

Fig. 1 Chemical structures of determined analytes

Standard solutions were diluted with methanol to obtain working standard solutions at the following concentrations for all analytes: 5, 10, 50, 100, 200, 500, 1000, and $2500 \mathrm{ng} /$ $\mathrm{mL}$. Calibrators and quality control (QC) samples were prepared by spiking the appropriate working solution into drug-free whole blood/urine samples. The final concentrations of the calibrators were: 0.5 (lower limit of quantification (LLOQ)), 1, 5, 10, 20, 50, 100, and 250 (upper limit of quantification (ULOQ)) $\mathrm{ng} / \mathrm{mL}$ blood/urine for U-47700, $\mathrm{N}$-ethylhexedrone, adinazolam and 4-CIC (in urine). ULOQ for determination of 4-CIC in whole blood and 4-CMC in blood/urine was $100 \mathrm{ng} / \mathrm{mL}$. QC samples were prepared by spiking blank human blood/urine to yield final concentrations at 10 and $100 \mathrm{ng} / \mathrm{mL}$ for all analytes.

For quantification of evidences, standard solutions were diluted with methanol to obtain working standard solutions at the concentration of analytes: 10 (LLOQ), 20, 50, 100, 200, 500, 1000, 2000, 5000, and 10,000 (ULOQ) ng/mL. $0.01 \mathrm{~mL}$ of each solution was placed into 2-mL Eppendorf tube and spiked with $0.01 \mathrm{~mL}$ appropriate IS (4-MMC$d_{3}$, fentanyl- $d_{5}$, diazepam- $d_{5}$ at concentration of $1 \mu \mathrm{g} / \mathrm{mL}$ ) and $0.08 \mathrm{~mL}$ methanol. After mixing, whole solution was transferred into glass vial. QC samples were performed at 20,500 and $5000 \mathrm{ng} / \mathrm{mL}$.

\section{Biological material preparation}

The sample procedure was carried out according to the previously described procedure by Zawadzki et al. [23] with minor modifications. Briefly, $0.2 \mathrm{~mL}$ biological material (femoral blood/urine) and $0.02 \mathrm{~mL}$ of methanolic IS mixture (4-MMC- $d_{3}$, fentanyl- $d_{5}$, diazepam- $d_{5}$ at concentration of $1 \mu \mathrm{g} / \mathrm{mL}$ ) were placed into $10-\mathrm{mL}$ plastic tube, then $0.2 \mathrm{~mL}$ of $0.5 \mathrm{M}$ ammonium carbonate $(\mathrm{pH} 9)$ was added. Liquid-liquid extraction was carried out for $10 \mathrm{~min}$ using $2 \mathrm{~mL}$ of ethyl acetate. The samples were centrifuged at $2540 \times g$ at $4{ }^{\circ} \mathrm{C}$ for $10 \mathrm{~min}$. The organic phase was placed into $2 \mathrm{~mL}$ Eppendorf tubes and evaporated to dryness under a stream of nitrogen $\left(\right.$ at $\left.40{ }^{\circ} \mathrm{C}\right)$. The dry residues were dissolved with methanol $(0.05 \mathrm{~mL})$ and transferred into glass inserts of autosampler vials. Because concentration of some determined substances were markedly above ULOQ, analyses were repeated with appropriate dilution. The injection volume was $2 \mu \mathrm{L}$. 
Fig. 2 Evidences found at the scene

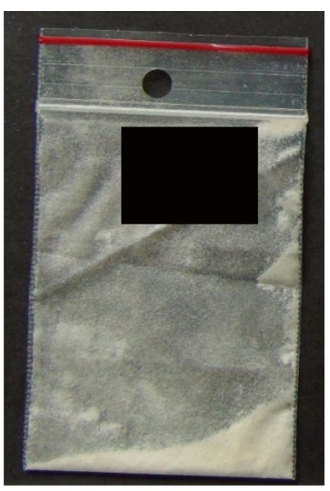

$N$-Ethylhexedrone

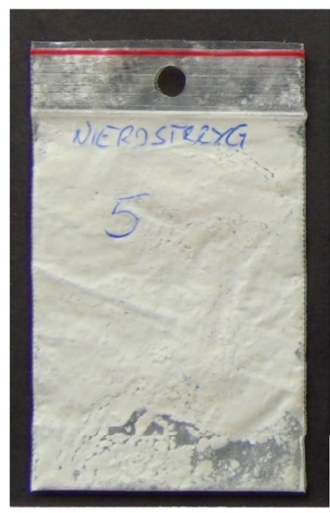

$\mathrm{U}-\mathbf{4 7 7 0 0}$

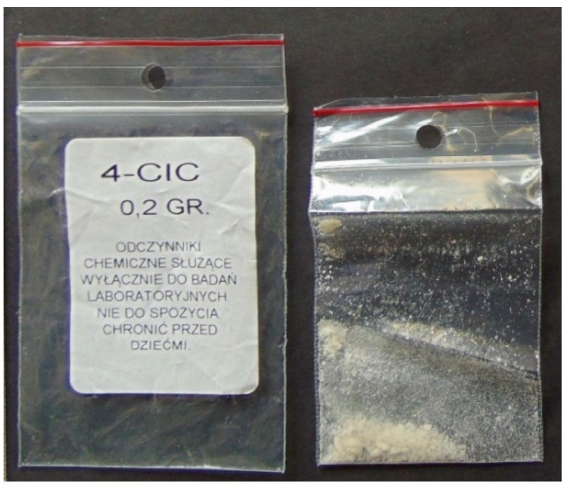

4-CIC

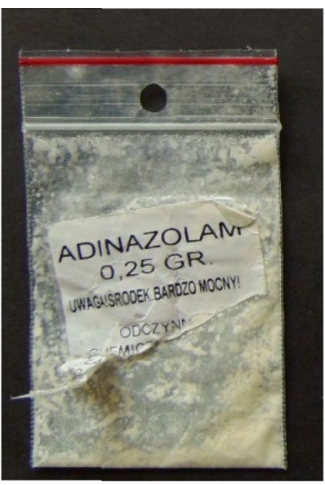

Adinazolam

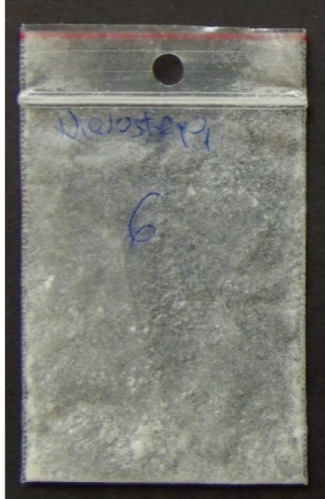

4-CMC

\section{Evidence preparation}

Approximately $100 \mathrm{mg}$ powder was placed into a $10-\mathrm{mL}$ centrifuge tube with $5 \mathrm{~mL}$ of methanol. Then tubes were placed into Ultrasonic bath for $30 \mathrm{~min}\left(\right.$ at $10{ }^{\circ} \mathrm{C}$ ) and centrifuged at $2540 \times g$ at $4{ }^{\circ} \mathrm{C}$ for $10 \mathrm{~min}$. The supernatant was diluted with methanol 1000-fold. Finally, $0.01 \mathrm{~mL}$ of diluted sample was placed into 2-mL Eppendorf tube and spiked with $0.01 \mathrm{~mL}$ appropriate IS (4-MMC- $d_{3}$, fentanyl$d_{5}$, diazepam- $d_{5}$ at concentration of $1 \mu \mathrm{g} / \mathrm{mL}$ ) and $0.08 \mathrm{~mL}$ methanol. The solution was transferred into glass inserts of autosampler vials. The injection volume was $2 \mu \mathrm{L}$.

To determine the content of pure substance in a given evidence, after determining the concentration of the substance, we performed calculations on the basis of the previous dilution of the evidence, its weight taken to the analysis and the mass of the entire evidence.

\section{Instrumentation}

Chromatographic analyses were performed using an ultrahigh performance liquid chromatograph (UHPLC Nexera X2; Shimadzu, Kyoto, Japan). The separation was done using a Kinetex XB-C18, $2.6 \mu \mathrm{m}$ particle size, $150 \times 2.1 \mathrm{~mm}$ i.d. column (Phenomenex, Torrance, CA, USA). The analytical conditions were identical to those presented previously in a study by Zawadzki et al. [23]; the mobile phase A: a mixture of $10 \mathrm{mM}$ ammonium formate and $0.1 \%$ formic acid in water, B: $0.1 \%$ formic acid in acetonitrile. The gradient applied: $0 \mathrm{~min}, 5 \% \mathrm{~B} ; 12 \mathrm{~min}, 98 \% \mathrm{~B} ; 14 \mathrm{~min}, 98 \% \mathrm{~B}$; and $15 \mathrm{~min}, 5 \% \mathrm{~B}$. Return to the initial gradient compositions (95\% $\mathrm{A} / 5 \% \mathrm{~B}$ ) was performed in $5 \mathrm{~min}$.

Additionally, we carried out determinations enabling the differentiation of chloromethcathinone isomers (2-, 34-CMC). For this purpose, we used the conditions described in our earlier work [18]. The gradient applied was as follows: 0 min, 5\% B; 11 min, 60\% B; 12 min, 98\% B; 14 min, 98\% $\mathrm{B}$; and $15 \mathrm{~min}, 5 \% \mathrm{~B}$. Return to the initial gradient compositions was also performed in $5 \mathrm{~min}$.

Analytes were detected using a triple-quadrupole mass spectrometer (LCMS-8050; Shimadzu). The spectrometer was equipped with an electrospray ionization (ESI) source; determination of the investigated substances was carried out in the positive multiple reaction monitoring (MRM) mode. The following MS parameters were fixed: heating gas flow, $10 \mathrm{~L} / \mathrm{min}$; drying gas flow, $10 \mathrm{~L} / \mathrm{min}$; nebulizing gas flow, $3 \mathrm{~L} / \mathrm{min}$; interface temperature, $250{ }^{\circ} \mathrm{C}$; desolvation line (DL) temperature, $200{ }^{\circ} \mathrm{C}$; heat block temperature, $350{ }^{\circ} \mathrm{C}$. 
A summary of precursor and product ions, collision energies, retention time, and internal standard group for each compound are presented in Table 1.

\section{Validation}

The method validation was performed in accordance with our previous paper [18]. The linearity, coefficient of determination $\left(R^{2}\right)$, LLOQ, precision, accuracy, recovery, matrix effect, and process efficiency were determined for both matrices (blood and urine). Intraday precision and accuracy were evaluated in five replicates over 1 day and interday precision and accuracy were evaluated as one replicate over five subsequent days. Precision, accuracy, recovery, matrix effect, and process efficiency were evaluated for NPS at the concentrations of 10 and $100 \mathrm{ng} / \mathrm{mL}$. Sertraline is routinely determined in our laboratory and had been previously validated.

\section{Results}

Table 2 shows the validation results of the method for blood and urine. All results of the method were within acceptable ranges; therefore, the method was implemented for the routine diagnosis.
In the presented case, the concentrations of drugs were determined as shown in Table 3. The same substances (separately) were found in 5 powders/crystals in evidences: U-47700 (12\% by weight), $N$-ethylhexedrone (54\%), adinazolam (14\%), 4-CIC (23\%), and 4-CMC (26\%). Ethanol was not detected in either material.

Figure 3 shows MRM chromatograms of U-47700, adinazolam and 4-CMC and metabolites of these substances in blood and urine in the present case.

In our case, we tentatively identified the following metabolites of U-47700 in both matrices: $N$-desmethyl U-47700, N,N-didesmethyl U-47700, and N-desmethylhydroxy U-47700 (Table 4). Figure S1 (in supplementary materials) presents the product ion spectra of metabolites of U-47700. We also detected two 4-CMC metabolites in analyzed materials: 1-(4-chlorophenyl)-(methylamino)1-propanol and 1-(4-chlorophenyl)-2-amino-1-propanol. Figure S2 (in supplementary materials) presents the mass spectra of both metabolites in urine of the cadaver. We also tried to identify adinazolam metabolites: $N$-desmethyl adinazolam and $N, N$-didesmethyl adinazolam (in blood and urine), and estazolam (in urine). Figure S3 (in supplementary materials) shows the product ion spectra of $N$-desmethyl adinazolam, $N, N$-didesmethyl adinazolam and estazolam, respectively, supporting the data described in Table 4.
Table 1 Multiple reaction monitoring (MRM) conditions used in the ultrahigh performance liquid chromatography-tandem mass spectrometry (UHPLCESI-MS/MS) analysis of substances and internal standards (ISs)

\begin{tabular}{|c|c|c|c|c|c|}
\hline Compounds & $\begin{array}{l}\text { Precursor ion } \\
(\mathrm{m} / \mathrm{z})\end{array}$ & Product ion $(\mathrm{m} / \mathrm{z})$ & $\begin{array}{l}\text { Collision } \\
\text { energy (V) }\end{array}$ & $\begin{array}{l}\text { Retention } \\
\text { time (min) }\end{array}$ & $\begin{array}{l}\text { Internal } \\
\text { standard } \\
\text { group }\end{array}$ \\
\hline $4-\mathrm{MMC}-d_{3}$ & 181.0 & $148.2^{\mathrm{a}}$ & & 4.32 & 1 \\
\hline 4-CMC & 198.0 & $\begin{array}{l}145.2^{\mathrm{a}} \\
144.1 \\
180.1\end{array}$ & $\begin{array}{l}-29 \\
-14\end{array}$ & 4.64 & 1 \\
\hline 4-CIC & 226.0 & $\begin{array}{l}131.1^{\mathrm{a}} \\
130.1 \\
166.1\end{array}$ & $\begin{array}{l} \\
-40 \\
-17\end{array}$ & 4.77 & 1 \\
\hline$N$-Ethylhexedrone & 220.0 & $\begin{array}{l}202.2^{\mathrm{a}} \\
91.0 \\
130.0\end{array}$ & $\begin{array}{l} \\
-24 \\
-34\end{array}$ & 5.23 & 1 \\
\hline U-47700 & 330.1 & $\begin{array}{l}285.1^{\mathrm{a}} \\
173.0 \\
174.0\end{array}$ & $\begin{array}{l} \\
-35 \\
-32\end{array}$ & 5.74 & 2 \\
\hline Fentanyl- $d_{5}$ & 342.1 & $\begin{array}{l}188.2 \\
105.2^{\mathrm{a}} \\
103.1\end{array}$ & $\begin{array}{l} \\
-39 \\
-55\end{array}$ & 5.78 & 2 \\
\hline Adinazolam & 352.2 & $\begin{array}{l}58.0^{\mathrm{a}} \\
335.4 \\
311.2\end{array}$ & $\begin{array}{l} \\
-24 \\
-23\end{array}$ & 5.38 & 3 \\
\hline Diazepam- $d_{5}$ & 290.0 & $\begin{array}{l}198.1^{\mathrm{a}} \\
154.1 \\
227.2\end{array}$ & $\begin{array}{l}-28 \\
-27\end{array}$ & 7.64 & 3 \\
\hline
\end{tabular}

4- $M M C-d_{3}$ 4-methylmethcathinone- $d_{3}, 4-C M C$ 4-chloromethcathinone, 4-CIC 4-chloro- $N$-isopropylcathi-

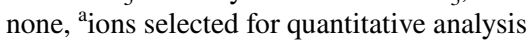




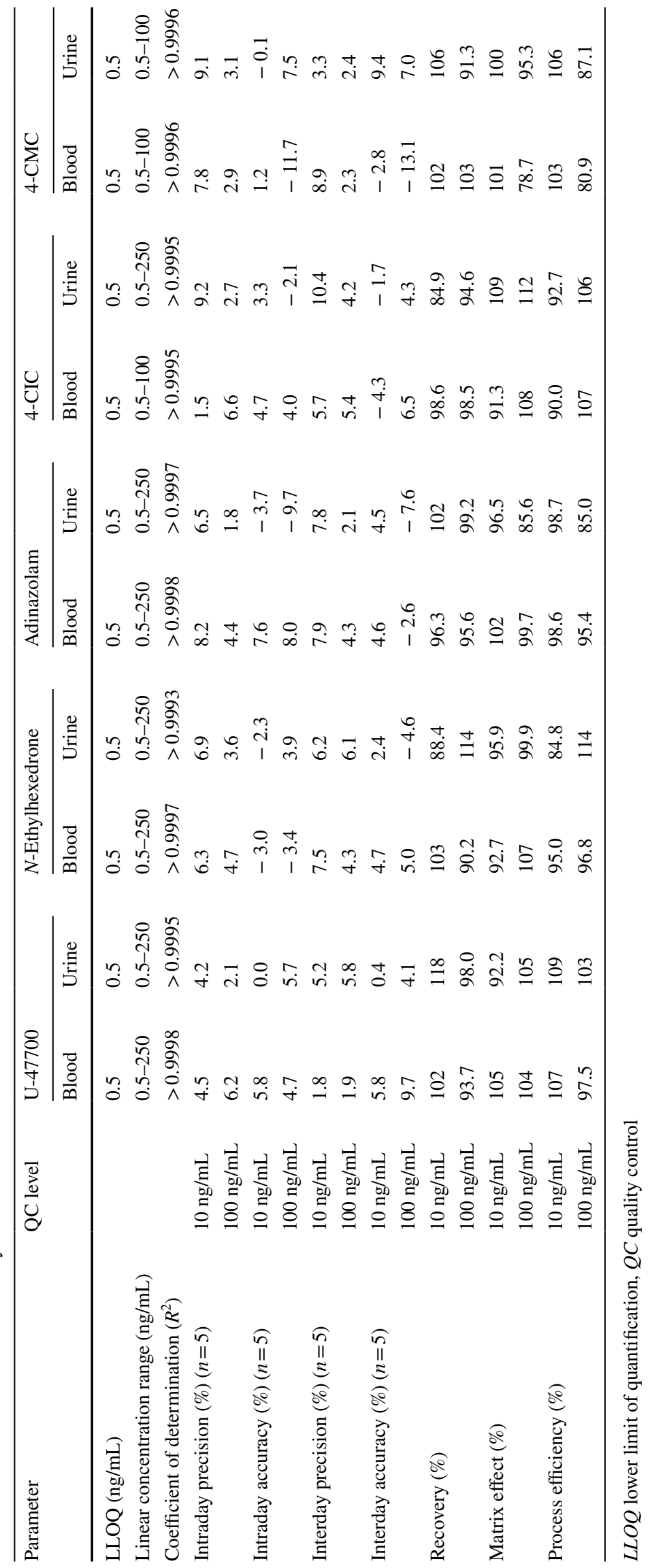


Table 3 Concentrations of xenobiotics in blood and urine samples collected from the cadaver at autopsy

\begin{tabular}{lll}
\hline Xenobiotic & \multicolumn{2}{l}{ Concentration $(\mathrm{ng} / \mathrm{mL})$} \\
\cline { 2 - 3 } & Blood & Urine \\
\hline U-47700 & 1470 & 3940 \\
Sertraline & 89.5 & 32.5 \\
$N$-Ethylhexedrone & 58.1 & 147 \\
Adinazolam & 18.0 & 82.1 \\
4-CIC & 8.0 & 130 \\
4-CMC & 1.7 & 417 \\
\hline
\end{tabular}

Table 4 shows comparison between identify product ions of metabolites from this work and those of previous papers.

Additionally, we decided to assess the stability of the xenobiotics determined in both biological materials
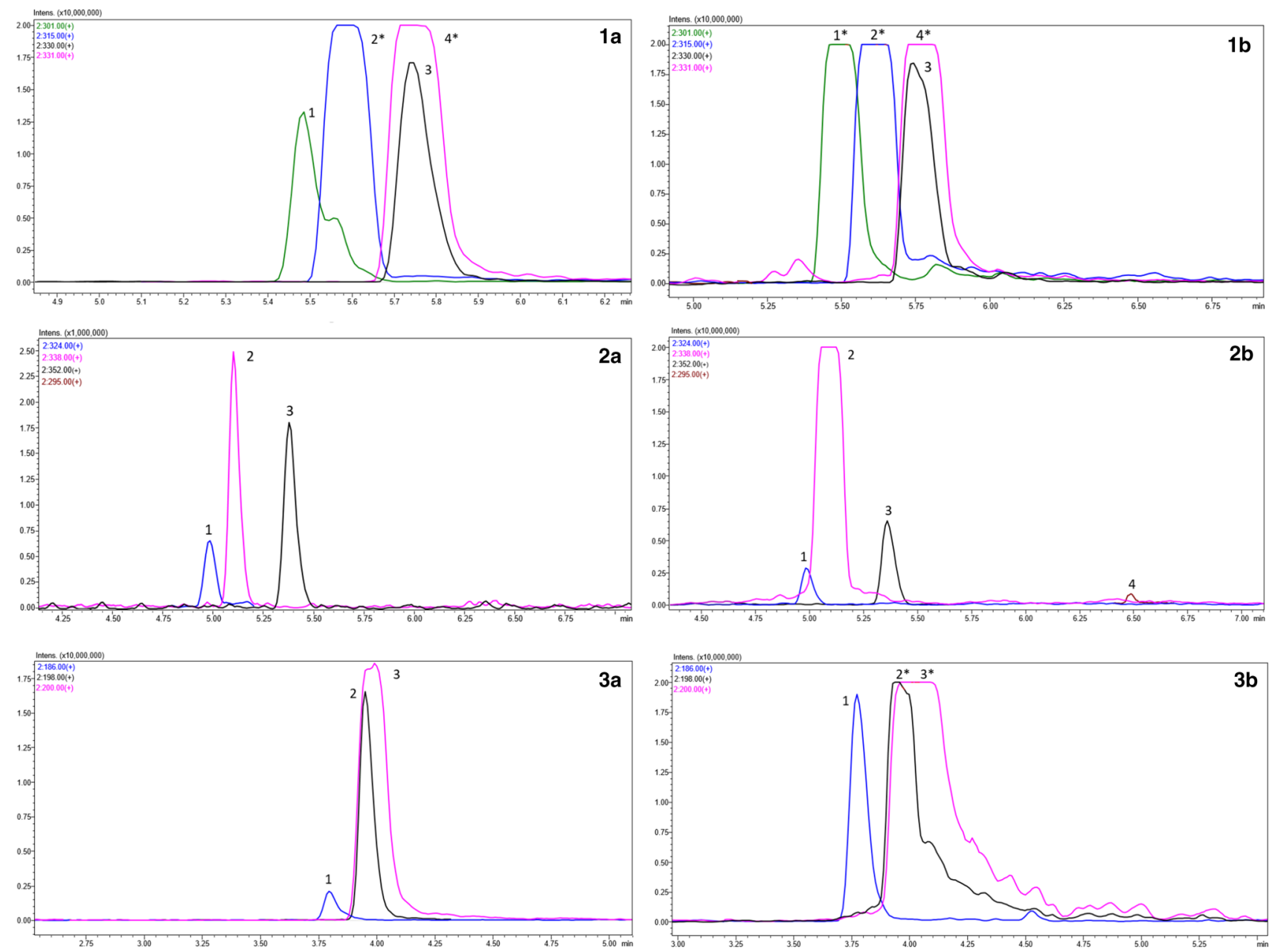

Fig. 3 Multiple reaction monitoring (MRM) chromatograms of: 1: U-47700 (3) and metabolies: $N, N$-didesmethyl U-47700 (1), $N$-desmthyl U-47700 (2), and $N$-desmethyl-hydroxy U-47700 (4); 2: adinazolam (3) and metabolites: $N, N$-didesmethyl adinazolam following storage in a refrigerator $\left(+4{ }^{\circ} \mathrm{C}\right)$ for 775 days ( 2 years and 1.5 months). The analyte was considered stable if the concentration differences were within $\pm 20 \%$ of the initial concentration. Table 5 presents the results of repeated analyses (percentage of individual xenobiotics in relation to the initial determination).

\section{Discussion}

Due to the woman's addiction to NPS, the concentrations of illicit drugs in her urine may have long fluctuated at certain levels. Accordingly, interpretation of toxicological results indicated lethal intoxication with the opioid U-47700, taken in combination with other substances: cathinones, benzodiazepines, and SSRIs (selective serotonin reuptake inhibitors). However, the data in the literature
(1), $N$-desmethyl adinazolam (2), and estazolam (4); 3: 4-CMC (2) and metbolites: 1-(4-chlorophenyl)-2-amino-1-propanol (1), 1-(4-chlorophenyl)-(methylamino)-1-propanol (3); a blood, b urine; * Overloaded peak 
Table 4 Comparison of product ions of metabolites of U-4700, adinazolam, and 4-CMC

\begin{tabular}{|c|c|c|c|c|c|}
\hline Substance & $\mathrm{RT}(\min )$ & $\begin{array}{l}\text { Precursor } \\
\text { ion }(m / z)\end{array}$ & $\mathrm{CE}(\mathrm{V})$ & Product ions $(\mathrm{m} / \mathrm{z})$ & References \\
\hline \multirow[t]{12}{*}{$N$-Desmethyl U-47700 } & 5.6 & 315.0 & $10 / 20$ & $284 *$ & This work \\
\hline & & & $20 / 35$ & $204 *$ & \\
\hline & & & $20 / 35$ & $173 *$ & \\
\hline & & & 35 & $145^{*}$ & \\
\hline & & & 35 & $81 *$ & \\
\hline & 6.07 & 315.1 & No information & 284 & Richeval et al. [34] \\
\hline & & & & 204 & \\
\hline & & & & 173 & \\
\hline & & & & 145 & \\
\hline & & & & 81 & \\
\hline & 1.5 & 315.1 & 33 & 1729 & Rojek et al. [7] \\
\hline & & & 57 & 1449 & \\
\hline \multirow[t]{12}{*}{$N, N$-Didesmethyl U-47700 } & 5.5 & 301.0 & 20 & $284 *$ & This work \\
\hline & & & $10 / 20$ & $270^{*}$ & \\
\hline & & & $20 / 35$ & $190 *$ & \\
\hline & & & $20 / 35$ & $173^{*}$ & \\
\hline & & & 35 & $145^{*}$ & \\
\hline & 5.95 & 301.1 & No information & 284 & Richeval et al. [34] \\
\hline & & & & 270 & \\
\hline & & & & 173 & \\
\hline & & & & 145 & \\
\hline & & & & 81 & \\
\hline & 1.4 & 301.1 & 13 & 270.0 & Rojek et al. [7] \\
\hline & & & 33 & 172.9 & \\
\hline \multirow[t]{9}{*}{$N$-Desmethyl-hydroxy U-47700 } & 5.7 & 331.0 & $10 / 20 / 35$ & $286^{*}$ & This work \\
\hline & & & $20 / 35$ & $206^{*}$ & \\
\hline & & & $20 / 35$ & $175^{*}$ & \\
\hline & & & 35 & $147 *$ & \\
\hline & & & $20 / 35$ & $81 *$ & \\
\hline & 5.64 & 331.1 & No information & 300 & Richeval et al. [34] \\
\hline & & & & 204 & \\
\hline & & & & 173 & \\
\hline & & & & 145 & \\
\hline \multirow[t]{10}{*}{$N$-Desmethyl adinazolam } & 5.1 & 338.1 & $10 / 20 / 35$ & $295^{*}$ & This work \\
\hline & & & $20 / 35$ & $267 *$ & \\
\hline & & & 35 & $241 *$ & \\
\hline & & & 35 & $205^{*}$ & \\
\hline & & & 35 & $138 *$ & \\
\hline & No information & 338.0 & $20,35,50$ & $295.0^{*}$ & Moosmann et al. [21] \\
\hline & & & & $267.0^{*}$ & \\
\hline & & & & $241.1^{*}$ & \\
\hline & & & & $205.1^{*}$ & \\
\hline & & & & $138.1^{*}$ & \\
\hline
\end{tabular}


Table 4 (continued)

\begin{tabular}{|c|c|c|c|c|c|}
\hline Substance & $\mathrm{RT}(\min )$ & $\begin{array}{l}\text { Precursor } \\
\text { ion }(m / z)\end{array}$ & $\mathrm{CE}(\mathrm{V})$ & Product ions $(\mathrm{m} / \mathrm{z})$ & References \\
\hline \multirow[t]{10}{*}{$N, N$ - Didesmethyl adinazolam } & \multirow[t]{5}{*}{5.0} & \multirow[t]{5}{*}{324.1} & $10 / 20 / 35$ & $307 *$ & \multirow[t]{5}{*}{ This work } \\
\hline & & & $20 / 35$ & $295^{*}$ & \\
\hline & & & $20 / 35$ & $279 *$ & \\
\hline & & & 35 & $267 *$ & \\
\hline & & & $20 / 35$ & $243 *$ & \\
\hline & \multirow[t]{5}{*}{ No information } & \multirow[t]{5}{*}{324.0} & & $307.0^{*}$ & \multirow[t]{5}{*}{ Moosmann et al. [21] } \\
\hline & & & & $295.0^{*}$ & \\
\hline & & & & $279.0^{*}$ & \\
\hline & & & & $267.1^{*}$ & \\
\hline & & & & $243.1^{*}$ & \\
\hline \multirow[t]{5}{*}{ 1-(4-Chlorophenyl)-(methylamino)-1-propanol } & \multirow[t]{5}{*}{4.0} & \multirow[t]{5}{*}{200.0} & $10 / 20$ & $182 *$ & \multirow[t]{5}{*}{ This work } \\
\hline & & & $10 / 20 / 35$ & $167 *$ & \\
\hline & & & $20 / 35$ & $125^{*}$ & \\
\hline & & & $20 / 35$ & $115^{*}$ & \\
\hline & & & 35 & $91 *$ & \\
\hline \multirow[t]{5}{*}{ 1-(4-Chlorophenyl)-2-amino-1-propanol } & \multirow[t]{5}{*}{3.8} & \multirow[t]{5}{*}{186.0} & $10 / 20$ & $168^{*}$ & \multirow[t]{5}{*}{ This work } \\
\hline & & & $10 / 20$ & $151 *$ & \\
\hline & & & $10 / 20$ & $132 *$ & \\
\hline & & & $10 / 20 / 35$ & $115^{*}$ & \\
\hline & & & 35 & $104 *$ & \\
\hline
\end{tabular}

$R T$ retention time, $C E$ collision energy

*Selected product ions

Table 5 Concentrations of xenobiotics in the analyzed case (in blood and in urine preserved with $\mathrm{NaF}$ ) after 775 days at $+4{ }^{\circ} \mathrm{C}$, expressed as a percentage $(\%)$ of the values determined during the first analysis

\begin{tabular}{lll}
\hline Xenobiotic & Blood (\%) & Urine $(\%)$ \\
\hline U-47700 & 61.0 & 55.6 \\
$N$-Ethylhexedrone & Not detected & 46.0 \\
Adinazolam & 52.8 & 47.6 \\
4-CIC & Not detected & Not detected \\
4-CMC & Not detected & 1.8 \\
Sertraline & 62.7 & 103 \\
\hline
\end{tabular}

indicate a strong synergistic interaction between U-47700 and benzodiazepines, a group which includes adinazolam. Therefore, the combination of adinazolam and U-47700 may have also contributed to her death. A similar combination case was reported by Koch et al. [24] who describes a fatal poisoning case of a 24-year-old man, in which he developed apnea following consumption of U-47700 in combination with flubromazepam. Despite the resuscitation efforts, he died after 6 days of hospitalization. It should be pointed out that the present of adinazolam is also a triazolo benzodiazepine that is very similar to flubromazepam in its structure. It is also known that cathinones may react with SSRIs, resulting in occurrence of the serotonin syndrome, but in the presented case this combination was not involved in death.

Taking into account reports of previous suicide attempts, we cannot exclude the possibility that in the described case a successful suicide attempt was made as a result of the ingestion of various substances.

Table S1 (in supplementary materials) presents a summary of U-47700 concentrations and toxicological analyses in deaths related to this substance. In many cases, e.g., described by Klavž et al. [25], in addition to U-47700, other substances, including NPS, were identified in biological materials. This is consistent with the EMCDDA's position that most drug-induced deaths are attributable to multiple drug toxicity [1].

According to Lowry et al. [26], in fatalities involving $\mathrm{U}-47700$, blood concentrations of this substance range from 0.090 to $1460 \mathrm{ng} / \mathrm{mL}$. Among the cases presented in Table S1, blood concentrations of U-47700 in cases of fatal intoxication with this substance alone were: in femoral blood 525-1490 ng/mL [9, 27], in cardiac blood 340-1347 [9, 28]; 
peripheral blood $190 \mathrm{ng} / \mathrm{mL}$ [28] and $380 \mathrm{ng} / \mathrm{mL}$ in nonspecified blood [29].

In multi-drug intoxication, concentrations of U-47700 were determined as follows: $13.8 \mathrm{ng} / \mathrm{mL}$ in subclavian blood (in combination with fentanyl, $10.9 \mathrm{ng} / \mathrm{mL}$ in subclavian blood) [30]; $360 \mathrm{ng} / \mathrm{mL}$ in femoral blood (other substances: 3-fluorophenmetrazine, amitriptyline, methamphetamine, diazepam, temazepam, flubromazolam, delorazepam) [10].

It appears that the low concentration of 4-CMC, especially in the blood $(1.7 \mathrm{ng} / \mathrm{mL}$ in blood, $417 \mathrm{ng} / \mathrm{mL}$ in urine), made a minor contribution to the woman's death. Tomczak et al. [20] determined the concentrations of 4-CMC in blood in nonfatal cases $(n=9)$ to be in the range $1.3-75.3 \mathrm{ng} /$ $\mathrm{mL}$, but in fatal cases $(n=6)$, in the range of $56.2-1870 \mathrm{ng} /$ $\mathrm{mL}$. However, it is worth considering previous reports [18, 31,32 ] suggesting the instability of 4-CMC in biological material. The time between the death and the autopsy in described case was 3 days. Therefore, it should be assumed that at the time of death the concentration of 4-CMC may have been several times higher or even more.

When interpreting concentrations of drugs, the synergistic effect of substances from the same group should be considered. In our case, we identified three substances from the group of synthetic cathinones, 4-CMC, $N$-ethylhexedrone and 4-CIC. Mikołajczyk et al. [17] described cases of three drivers whose blood contained $N$-ethylhexedrone. The concentrations of $N$-ethylhexedrone determined by the authors were 34,37 , and $8 \mathrm{ng} / \mathrm{mL}$. Adamowicz et al. [16] described the case of the death of an 18-year-old male addicted to drugs and NPS; apart from $N$-ethylhexedrone $(1351 \mathrm{ng} / \mathrm{mL}$ in urine, $34 \mathrm{ng} / \mathrm{mL}$ in bile, $3 \mathrm{ng} / \mathrm{mL}$ in bloody fluid from the lung, and $5 \mathrm{ng} / \mathrm{g}$ in tissue homogenate from brain), the following drugs were found: 4-CMC $(1477 \mathrm{ng} / \mathrm{mL}$ in urine, and $41 \mathrm{ng} / \mathrm{mL}$ in bile), $\alpha$-PiHP, benzoylecgonine, and MDMA. Kovács et al. [15] described fatal intoxication with a combination of $\mathrm{N}$-ethylhexedrone and ADB-FUBINACA; the concentration in the blood of $N$-ethylhexedrone was $285 \mathrm{ng} / \mathrm{mL}$, while the concentration of ADB-FUBINACA was $0.08 \mathrm{ng} /$ $\mathrm{mL}$. Dunlop et al. [33] discussed acute toxicity related to the use by a 56-year-old man of 3-hydroxyphencyclidine and $\mathrm{N}$-ethylhexedrone. Apart from these two substances and their metabolites, clephedrone and its metabolites were detected in his serum and 3-methoxy-PCP and 11-nor-9-carboxyTHC in his urine. Paracetamol, atenolol, diazepam, and their metabolites were also detected in the tested materials, but it was concluded that their presence was the result of medical therapy.

To our knowledge, there are no reports on postmortem concentrations of 4-CIC and adinazolam. Detailed characterization on their chemistry, pharmacology, and toxicology remains to be explored.

Evidences found at the scene of an incident often support the toxicological analysis studies performed on the corresponding human matrices. In this case we have described, all substances secured at the scene of the incident were detected in the postmortem matrices. Klavž et al. [25] described a case of the failed suicide attempt of a 38-year-old man who took synthetic cathinones and synthetic cannabinoids. Qualitative analysis of five grip-seal plastic bags containing powders/crystals demonstrated the presence of AB-CHMINACA, AB-FUBINACA, $\alpha$-PHP, $\alpha$ -PVP, and 4-CMC in individual plastic bags. These substances (except 4-CMC) were also detected in the contents of the patient's stomach, whereas $\alpha$-PHP and $\alpha$-PVP were detected in his urine. Coopman et al. [30] described a case of acute intoxication with a combination of fentanyl and U-47700. Qualitative analysis of the powder located at the scene indicated fentanyl $(0.0035 \%)$ and U-47700 $(0.0012 \%)$. McIntyre et al. [28] described a case of fatal $\mathrm{U}-47700$ poisoning in a 46-year-old man with its concentration in heart blood being $340 \mathrm{ng} / \mathrm{mL}$. Toxicological analysis of powder located at the scene confirmed that it contained only U-47700. Richeval et al. [34] conducted a toxicological analysis of $70 \mathrm{mg}$ of white powder discovered in April 2017 in the case of a 29-year-old man. Scientists determined the U-47700 content in the evidence at $84 \%$.

The concentration of U-47700 after 775 days at $+4{ }^{\circ} \mathrm{C}$ decreased by $39.0 \%$ in blood and by $44.4 \%$ in urine (Table 5). This, given the long study period, may indicate the relatively high stability of U-47700 in postmortem blood and urine, Mohr et al. [35] performed stability studies on U-47700, U-50488, and furanyl fentanyl at low (5 ng/ $\mathrm{mL})$ and high $(80 \mathrm{ng} / \mathrm{mL})$ concentrations at temperatures of +4 and $-20^{\circ} \mathrm{C}$ on days 2,3 , and 10 . All of the tested analytes, including U-47700, were stable over the time period studied. Smith et al. [36] determined the stability of U-47700 and its two metabolites ( $N$-desmethyl U-47700 and $N, N$-didesmethyl U-47700) at low $(0.3 \mathrm{ng} / \mathrm{mL}$ and $1.5 \mathrm{ng} /$ $\mathrm{mL}$, respectively) and high $(80 \mathrm{ng} / \mathrm{mL})$ concentrations in human plasma stored in various conditions: tested at $+22^{\circ} \mathrm{C}$ $(n=3)$ for $24 \mathrm{~h}$, at $+4{ }^{\circ} \mathrm{C}(n=3)$ for $72 \mathrm{~h}$, in 3 freeze/thaw cycles $(n=3)$, and for $72 \mathrm{~h}$ in an autosampler $(n=3)$. For this period of time the stability bias for all three substances ranged from -10.6 to $4.2 \%$, which was considered stable [36]. Fleming et al. [37] investigated the stability of U-47700 in a fortified drug-free urine sample at a concentration of $12.5 \mathrm{ng} / \mathrm{mL}$. Stability was studied at room temperature $\left(21-27^{\circ} \mathrm{C}\right)$ for $16 \mathrm{~h}$, in an autosampler $\left(+6{ }^{\circ} \mathrm{C}\right)$ for $72 \mathrm{~h}$, and in three freeze-thaw cycles $\left(-15^{\circ} \mathrm{C}\right)$. The substance was found to be stable in all conditions. The stability of U-47700 was also confirmed by Rojek et al. [7], whose fortified blood with U-47700 and its metabolites ( $N$-desmethyl $\mathrm{U}-47700, N, N$-didesmethyl U-47700) at low concentrations $(25 \mathrm{ng} / \mathrm{mL})$ and stored it at $-30{ }^{\circ} \mathrm{C},+3{ }^{\circ} \mathrm{C}$, and $+20^{\circ} \mathrm{C}$. The analyses were performed after $1,7,14$, and 21 days of 
storage. U-47700 and its two metabolites were stable in the blood for 21 days at all temperatures tested.

A similar reduction in concentration was observed for adinazolam (Table 5). After 775 days, the concentration of this xenobiotic dropped by $47.2 \%$ in blood and $52.4 \%$ in urine. Melo et al. [38] examined the stability of four benzodiazepines (ketazolam, estazolam, lorazepam, and chlordiazepoxide) in three biological materials (blood, bile, and vitreous humor) on day 0 and after 1, 2, 4, 8, 12, 16, 20 , and 24 weeks (blood with $\mathrm{NaF}$ only on day 0 and after 24 weeks, and vitreous humor on day 0 and after 12 and 24 weeks) within the concentrations usually detected in forensic intoxication cases. The selected conditions were temperatures of approximately $+25,+4,-20$, and $-80^{\circ} \mathrm{C}$. The authors [38] showed that ketazolam was the least stable benzodiazepine tested. After $1-2$ weeks at $+25{ }^{\circ} \mathrm{C}$ and after 8-12 weeks at $+4{ }^{\circ} \mathrm{C}$, the concentration of ketazolam was no longer detectable in any of the studied samples. It is noteworthy that the addition of $\mathrm{NaF}$ to the samples had no protective effect against degradation. Additionally, the presence of diazepam as a degradation product of ketazolam was demonstrated in the tested samples stored at temperatures above $0{ }^{\circ} \mathrm{C}$. Similarly, degradation in biological matrices was observed in chlordiazepoxide at temperatures above $0{ }^{\circ} \mathrm{C}$, whereas, after 6 months, lorazepam remained stable in all samples stored at -20 and $-80^{\circ} \mathrm{C}$, but was unstable at temperatures above $0{ }^{\circ} \mathrm{C}$. Estazolam proved to be the most stable benzodiazepine. Estazolam concentrations in all samples were stable for 6 months when stored at temperatures below $0{ }^{\circ} \mathrm{C}$ and at $+4{ }^{\circ} \mathrm{C}$ [38]. Considering the variation in stability observed in different benzodiazepines, the stability of adinazolam seems relatively high.

In the biological materials tested, sertraline was characterized by the highest level of stability. After 775 days at $+4{ }^{\circ} \mathrm{C}$, concentrations of substances in the blood dropped by $37.7 \%$, while the concentrations in the urine were stable throughout the research period. The stability of sertraline in human plasma was confirmed by Yue et al. [39], who tested short-term stability (the first $2 \mathrm{~h}$ at room temperature, the second $2 \mathrm{~h}$ as a ready-to-inject sample stored in an autosampler at $+4{ }^{\circ} \mathrm{C}$ for $12 \mathrm{~h}$ ), long-term stability $\left(-20^{\circ} \mathrm{C}\right.$ for 30 days), and freeze-thaw stability $\left(-20\right.$ to $+25^{\circ} \mathrm{C}$ on consecutive days). Stability studies were performed at three different concentrations: low $(2.0 \mathrm{ng} / \mathrm{mL})$, medium $(20.0 \mathrm{ng} /$ $\mathrm{mL})$, and high $(80.0 \mathrm{ng} / \mathrm{mL})$. Sertraline was found to be stable in human plasma at all concentrations (differences were within $\pm 15 \%$ of the initial concentration).

In our research, substances from the group of synthetic cathinones proved the most unstable. 4-CIC was detectable in neither blood nor urine; 4-CMC and $N$-ethylhexedrone were not detectable in blood, whereas in urine the concentration of $4-\mathrm{CMC}$ was less than $2 \%$ and that of $\mathrm{N}$-ethylhexedrone was $46 \%$ as compared to the first analysis. As previously mentioned, 4-CMC a highly unstable substance $[18,31,32]$. In our earlier paper, we showed a decrease in the concentration of 4-CMC in authentic human serum by $65 \%$ after 3 days at $+4{ }^{\circ} \mathrm{C}[31]$. On the other hand, in authentic human postmortem blood, the concentration of 4-CMC dropped after 7 days at $+4{ }^{\circ} \mathrm{C}$ by $39 \%$, and in vitreous humor by 53\% [18]. Adamowicz and Malczyk [32], in blood and urine samples fortified with standard solution of 4-CMC, estimated the half-life of $4-\mathrm{CMC}$ at $+5{ }^{\circ} \mathrm{C}$ for 1 day in blood and 2.4 months in urine. The total degradation time of 4-CMC at $+5{ }^{\circ} \mathrm{C}$ was estimated at 3.9 months in blood and 4.4 months in urine. Wagmann et al. [40], who conducted toxicokinetic studies of 4-CMC, $N$-ethylnorpentylone, $N$-ethylhexedrone and 4-fluoro- $\alpha$-pyrrolidinohexiophenone, investigated the stability of substances in pooled human liver microsomes. The half-life demonstrated in vitro for $\mathrm{N}$-ethylhexedrone was $85 \mathrm{~min}$. To our knowledge, no detailed studies on the stability of 4-CIC and $N$-ethylhexedrone in blood and urine have been published to date.

\section{Conclusions}

The article presents the quantification of U-47700, $N$-ethylhexedrone, adinazolam, 4-CIC, and 4-CMC in postmortem blood and urine, and also quantification of these substances in evidences found at the scene of the fatal incident. No cases presenting concentrations of adinazolam and 4-CIC in postmortem human matrices have been reported to date. In addition, we reported stability results for the identified NPS in blood and urine stored for as long as 775 days at $+4{ }^{\circ} \mathrm{C}$.

\section{Compliance with ethical standards}

Conflict of interest The authors declare that they have no conflict of interest.

Ethical approval All procedures performed in this study involving human participants were in accordance with the ethical standards of the international and/or national committee and with the 1964 Declaration of Helsinki and its later amendments or comparable ethical standards. Blood and urine collections from cadaver were made by judicial authorities, and the samples were sent to our institute for toxicological analysis to their request. This article does not contain any studies with living human participants or animals performed by any of the authors.

Open Access This article is licensed under a Creative Commons Attribution 4.0 International License, which permits use, sharing, adaptation, distribution and reproduction in any medium or format, as long as you give appropriate credit to the original author(s) and the source, provide a link to the Creative Commons licence, and indicate if changes were made. The images or other third party material in this article are included in the article's Creative Commons licence, unless indicated otherwise in a credit line to the material. If material is not included in 
the article's Creative Commons licence and your intended use is not permitted by statutory regulation or exceeds the permitted use, you will need to obtain permission directly from the copyright holder. To view a copy of this licence, visit http://creativecommons.org/licenses/by/4.0/.

\section{References}

1. European Monitoring Centre for Drugs and Drug Addiction (2019) Drug-related deaths and mortality in Europe. https:// www.emcdda.europa.eu/system/files/publications/11485/20193 286_TD0319444ENN_PDF.pdf. Accessed 22 Aug 2020

2. Pichini S, Zaami S, Paciffici R, Tagliabracci A, Busardò FP (2019) The challenge posed by new synthetic opioids: pharmacology and toxicology. Front Pharmacol 10:563. https://doi.org/10.3389/fphar 2019.0056

3. Vlaams expertisecentrum Alcohol en andere Drugs (2017) Overlijden na gebruik van U-47700 en 3-MeO-PCP (04/09/2017). https ://www.vad.be/nodes/overlijdennagebruikvan3meopcpenhoog gedoseerdextc27062017clone/nl. Accessed 22 Aug 2020 (in Dutch)

4. European Monitoring Centre for Drugs and Drug Addiction (2019) Belgium Country Drug Report 2019. https://www.emcdd a.europa.eu/system/files/publications/11345/belgium-cdr-2019_0. pdf. Accessed 22 Aug 2020

5. European Monitoring Centre for Drugs and Drug Addiction (2019) Finland Country Drug Report 2019. https://www.emcdd a.europa.eu/system/files/publications/11336/finland-cdr-2019_0. pdf. Accessed 22 Aug 2020

6. European Monitoring Centre for Drugs and Drug Addiction (2019) Italy Country Drug Report 2019. https://www.emcdd a.europa.eu/system/files/publications/11329/italy-cdr-2019_0. pdf. Accessed 22 Aug 2020

7. Rojek S, Romańczuk A, Kula K, Synowiec K, Kłys M (2019) Quantification of U-47700 and it metabolites: $N$-desmethylU-47700 and N, $N$-didesmethyl-U-47700 in 12 autopsy blood samples employing SPE/LC-ESI-MS-MS. Forensic Toxicol 37:339-349. https://doi.org/10.1007/s11419-019-00464-3

8. Drummer OH (2019) Fatalities caused by novel opioids: a review. Forensic Sci Res 4:95-110. https://doi.org/10.1080/20961 790.2018 .1460063 (open access article)

9. Dziadosz M, Klintschar M, Teske J (2017) Postmortem concentration distribution in fatal case involving the synthetic opioid U-47700. Int J Legal Med 131:1555-1556. https://doi. org/10.1007/s00414-017-1593-7 (open access article)

10. Ellefsen KN, Taylor EA, Simmons P, Willoughby V, Hall BJ (2017) Multiple drug-toxicity involving novel psychoactive substances, 3-fluorophenmetrazine and U-47700. J Anal Toxico 41:765-770. https://doi.org/10.1093/jat/bkx060 (open access article)

11. Kyei-Baffour K, Lindsley CW (2020) DARK classics in chemical neuroscience: U- 47700. ACS Chem Neurosci. https://doi. org/10.1021/acschemneuro.0c00330 (ahead of print open access article)

12. Nikolau P, Katselou M, Papoutsis I, Spiliopoulou C, Athanaselis $S$ (2017) U-47700. An old opioid becomes a recent danger. Forensic Toxicol 35:11-19. https://doi.org/10.1007/s11419-016-0347-4 (open access article)

13. World Health Organisation (2016) U-47700 Critical review report. Agenda item 4.1. https://www.who.int/medicines/access/contr olled-substances/4.1_U-47700_CritReview.pdf?ua=1. Accessed 22 Aug 2020

14. European Monitoring Centre for Drugs and Drug Addiction (2018) European drug report 2018: trends and development. https ://doi.org/10.2810/800331
15. Kovács K, Kereszty É, Berkecz R, Tiszlavicz L, Sija É, Körmöczi T, Jenei N, Révész-Schmehl H, Institóris L (2019) Fatal intoxication of a regular drug user following $N$-ethyl-hexedrone and ADB-FUBINACA consumption. J Forensic Leg Med 65:92-100. https://doi.org/10.1016/j.jflm.2019.04.012 (open access article)

16. Adamowicz P, Jurczyk A, Gil D, Szustowski S (2020) A case of intoxication with a new cathinone derivative $\alpha$-PiHP - a presentation of concentrations in biological specimens. Leg Med 42:101626. https://doi.org/10.1016/j.legalmed.2019.101626 (open access article)

17. Mikołajczyk A, Adamowicz P, Tokarczyk B, Sekuła K, Gieroń J, Wrzesień W, Stanaszek R (2017) Determination of $N$-ethylhexedrone, a new cathinone derivative, in blood collected from drivers-analysis of three cases. Probl Forensic Sci 109:53-63 (open access article)

18. Nowak K, Szpot P, Zawadzki M (2020) The stability of 4-chloromethcathinone in blood and vitreous humor. J Forensic Sci 65:1784-1790. https://doi.org/10.1111/1556-4029.14454

19. Fels H, Lottner-Nau S, Sax T, Roider G, Graw M, Auwärter V, Musshoff F (2019) Postmortem concentrations of the synthetic opioid U-47700 in 26 fatalities associated with the drug. Forensic Sci Int 301:20-28. https://doi.org/10.1016/j.forsc iint.2019.04.010

20. Tomczak E, Woźniak MK, Kata M, Wiergowski M, Szplech B, Biziuk M (2018) Blood concentrations of new psychoactive substance 4-chloromethcathinone (4-CMC) determined in 15 forensic cases. Forensic Toxicol 36:476-785. https://doi.org/10.1007/ s11419-018-0427-8 (open access article)

21. Moosmann B, Bisel P, Franz F, Huppertz LM, Auwärter V (2016) Characterization and in vitro phase I microsomal metabolism of designer benzodiazepines - an update comprising adinazolam, cloniprazepam, fonazepam, 3-hydroxyphenazepam, metizolam, and nitrazolam. J Mass Spectrom 51:1080-1089. https://doi. org/10.1002/jms. 3840

22. European Monitoring Centre for Drugs and Drug Addiction (2016) EMCDDA-Europol 2015 annual report on the implementation of Council Decision 2005/387/JHA. https://doi.org/https:// doi.org/10.2810/932574

23. Zawadzki M, Nowak K, Szpot P (2020) Fatal intoxication with $N$-ethylpentylone: a case report and method for determining $\mathrm{N}$-ethylpentylone in biological material. Forensic Toxicol 38:255263. https://doi.org/10.1007/s11419-019-00483-0 (open access article)

24. Koch K, Auwärter V, Hermanns-Clausen M, Wilde M, Neukamm MA (2018) Mixed intoxication by the synthetic opioid U-47700 and the benzodiazepine flubromazepam with lethal outcome: pharmacokinetic data. Drug Test Anal 10:1336-1341. https:// doi.org/10.1002/dta.2391

25. Klavž J, Gorenjak M, Marinšek M (2016) Suicide attempt with a mix of synthetic cannabinoids and synthetic cathinones: case report of non-fatal intoxication with $\mathrm{AB}-\mathrm{CHMINACA}, \mathrm{AB}-$ FUBINACA, alpha-PHP, alpha-PVP and 4-CMC. Forensic Sci Int 265:121-124. https://doi.org/10.1016/j.forsciint.2016.01.018

26. Lowry J, Truver MT, Swortwood MJ (2019) Quantification of seven novel synthetic opioids in blood using LC-MS/MS. Forensic Toxicol 37:215-223. https://doi.org/10.1007/s11419-018-0458-1 (open access article)

27. Elliott SP, Brandt SD, Smith C (2016) The first reported fatality associated with the synthetic opioid 3,4-dichloro-N-[2(dimethylamino)cyclohexyl]-N-methylbenzamide (U-47700) and implications for forensic analysis. Drug Test Anal 8:875-879. https://doi.org/10.1002/dta.1984

28. McIntyre IM, Gary RD, Joseph S, Stabley R (2017) A fatality related to the synthetic opioid U-47700: postmortem concentration distribution. J Anal Toxicol 41:158-160. https://doi. org/10.1093/jat/bkw124 (open access article) 
29. Gerace E, Salomone A, Luciano C, Di Corcia D, Vincenti M (2018) First case in Italy of fatal intoxication involving the new opioid U-47700. Fornt Pharmacol 9:747. https://doi.org/10.3389/ fphar.2018.00747 (open access article)

30. Coopman V, Blanckaert P, Van Parys G, Van Calenbergh S, Cordonnier J (2016) A case of acute intoxication due to combined use of fentanyl and 3,4-dichloro-N-[2-(dimethylamino)cyclohexyl]-Nmethylbenzamide (U-47700). Forensic Sci Int 266:68-72. https:// doi.org/10.1016/j.forsciint.2016.05.001 (open access article)

31. Nowak K, Szpot P, Zawadzki M (2019) Unstability of 4-CMC in human serum specimen. Forensic Toxicol 37:261-264. https://doi. org/10.1007/s11419-018-0455-4 (open access article)

32. Adamowicz P, Malczyk A (2019) Stability of synthetic cathinones in blood and urine. Forensic Sci Int 295:36-45. https://doi. org/10.1016/j.forsciint.2018.12.001 (open access article)

33. Dunlop LC, Wood D, Archer J, Hudson S, Dargan P (2020) Severe toxicity to the new psychoactive substances 3-hydroxyphencyclidine and $\mathrm{N}$-ethylhexedrone: an analytically confirmed case report. J Med Toxicol 16:67-70. https://doi.org/10.1007/s1318 1-019-00734-x

34. Richeval C, Gaulier J-M, Romeuf L, Allorge D, Gaillard Y (2019) Case report: relevance of metabolite identification to detect new synthetic opioid intoxications illustrated by U-47700. Int J Legal Med 133:133-142. https://doi.org/10.1007/s00414-018-1969-3 (open access article)

35. Mohr ALA, Friscia M, Papsun D, Kacinko SL, Buzby D, Logan BK (2016) Analysis of novel synthetic opioids U-47700, U-50488 and furanyl fentanyl by LC-MS/MS in postmortem casework. J Anal Toxicol 40:709-717. https://doi.org/10.1093/jat/bkw086 (open access article)
36. Smith CR, Truver MT, Swortwood MJ (2019) Quantification of U-47700 and its metabolites in plasma by LC-MS/MS. J Chromatogr B 1112:41-47. https://doi.org/10.1016/j.jchromb.2019.02.026 (open access article)

37. Fleming SW, Cooley JC, Johnson L, Frazee CC, Domanski K, Kleinschmidt K, Garg U (2017) Analysis of U-47700, a novel synthetic opioid, in human urine by LC-MS-MS and LC-QToF. J Anal Toxicol 41:173-180. https://doi.org/10.1093/jat/bkw131 (open access article)

38. Melo P, Bastos ML, Teixeira HM (2012) Benzodiazepine stability in postmortem samples stored at different temperatures. J Anal Toxicol 36:52-60. https://doi.org/10.1093/jat/bkr008 (open access article)

39. Yue X-H, Wang Z, Tian D-D, Zhang J-W, Zhu K, Ye Q (2016) Determination of sertraline in human plasma by UPLC-MS/MS and its application to a pharmacokinetic study. J Chromatogr Sci 54:195-199. https://doi.org/10.1093/chromsci/bmv128 (open access article)

40. Wagmann L, Manier SK, Eckstein N, Maurer HH, Mayer MR (2020) Toxicokinetic studies of the four new psychoactive substances 4-chloroethcathinone, $N$-ethylnorpentylone, $N$-ethylhexedrone, and 4-fluoro-alpha-pyrrolidinohexiophenone. Forensic Toxicol 38:59-69. https://doi.org/10.1007/s11419-019-00487-w (open access article)

Publisher's Note Springer Nature remains neutral with regard to jurisdictional claims in published maps and institutional affiliations. 